\title{
Author Correction: 137 ancient human genomes from across the Eurasian steppes
}

\author{
De Barros Damgaard, Peter; Marchi, Nina; Rasmussen, Simon; Peyrot, Michaël; Renaud, Gabriel; \\ Korneliussen, Thorfinn; Moreno-Mayar, J. Víctor; Pedersen, Mikkel Winther; Goldberg, Amy; Usmanova, \\ Emma \\ Total number of authors: \\ 77
}

Published in:

Nature

Link to article, DOI:

10.1038/s41586-018-0488-1

Publication date:

2018

Document Version

Publisher's PDF, also known as Version of record

Link back to DTU Orbit

Citation (APA):

De Barros Damgaard, P., Marchi, N., Rasmussen, S., Peyrot, M., Renaud, G., Korneliussen, T., Moreno-Mayar, J. V., Pedersen, M. W., Goldberg, A., Usmanova, E., Baimukhanov, N., Loman, V., Hedeager, L., Pedersen, A. G., Nielsen, K., Afanasiev, G., Akmatov, K., Aldashev, A., Alpaslan, A., ... Willerslev, E. (2018). Author Correction: 137 ancient human genomes from across the Eurasian steppes. Nature, 557. https://doi.org/10.1038/s41586-018-0488-1

\section{General rights}

Copyright and moral rights for the publications made accessible in the public portal are retained by the authors and/or other copyright owners and it is a condition of accessing publications that users recognise and abide by the legal requirements associated with these rights.

- Users may download and print one copy of any publication from the public portal for the purpose of private study or research.

- You may not further distribute the material or use it for any profit-making activity or commercial gain

- You may freely distribute the URL identifying the publication in the public portal 
CORRECTION

https://doi.org/10.1038/s41586-018-0488-1

\section{Author Correction: 137 ancient human genomes from across the Eurasian steppes}

Peter de Barros Damgaard, Nina Marchi, Simon Rasmussen, Michael Peyrot, Gabriel Renaud, Thorfinn Korneliussen, J. Victor Moreno-Mayar, Mikkel Winther Pedersen, Amy Goldberg, Emma Usmanova, Nurbol Baimukhanov, Valeriy Loman, Lotte Hedeager, Anders Gorm Pedersen, Kasper Nielsen, Gennady Afanasiev, Kunbolot Akmatov, Almaz Aldashev, Ashyk Alpaslan, Gabit Baimbetov, Vladimir I. Bazaliiskii, Arman Beisenov, Bazartseren Boldbaatar, Bazartseren Boldgiv, Choduraa Dorzhu, Sturla Ellingvag, Diimaajav Erdenebaatar, Rana Dajani, Evgeniy Dmitriev, Valeriy Evdokimov, Karin M. Frei, Andrey Gromov, Alexander Goryachev, Hakon Hakonarson, Tatyana Hegay, Zaruhi Khachatryan, Ruslan Khaskhanov, Egor Kitov, Alina Kolbina, Tabaldiev Kubatbek, Alexey Kukushkin, Igor Kukushkin, Nina Lau, Ashot Margaryan, Inga Merkyte, Ilya V. Mertz, Viktor K. Mertz, Enkhbayar Mijiddorj, Vyacheslav Moiyesev, Gulmira Mukhtarova, Bekmukhanbet Nurmukhanbetov, Z. Orozbekova, Irina Panyushkina, Karol Pieta, Vaclav Smrčka, Irina Shevnina, Andrey Logvin, Karl-Goran Sjogren, Tereza Štolcova, Angela M. Taravella, Kadicha Tashbaeva, Alexander Tkachev, Turaly Tulegenov, Dmitriy Voyakin, Levon Yepiskoposyan, Sainbileg Undrakhbold, Victor Varfolomeev, Andrzej Weber, Melissa A. Wilson Sayres, Nikolay Kradin, Morten E. Allentoft, Ludovic Orlando, Rasmus Nielsen, Martin Sikora, Evelyne Heyer, Kristian Kristiansen \& Eske Willerslev

Correction to: Nature https://doi.org/10.1038/s41586-018-0094-2, published online 09 May 2018.

In this Article, Angela M. Taravella and Melissa A. Wilson Sayres should have been listed as authors, with the affiliation: School of Life Sciences, Center for Evolution and Medicine, The Biodesign Institute, Arizona State University, Tempe, AZ, USA. These authors provided an overview of major Y-chromosomal haplogroups in Supplementary Information Section 8. The author list and Author Information section have been corrected online. 